\title{
RELASI SISTEM TANDA VERBAL DAN TANDA VISUAL PADA IKLAN ROKOK DI YOUTUBE
}

\author{
(The Relation of Verbal dan Visual Signs System \\ in Cigarette Advertisements in Youtube)
}

\author{
Albertus Purwaka, Paul Diman, Ina Nurensia Maleyati \\ Pendidikan Bahasa dan Sastra Indonesia, FKIP Universitas Palangka Raya \\ Jalan Yos Sudarso Kampus UPR Tunjung Nyaho Palangka Raya \\ Posel: paul.diman@pbsi.upr.ac.id
}

(Naskah diterima 23 Oktober 2020-Direvisi 18 Desember 2020-Disetujui 18 Desember 2020)

\begin{abstract}
This study discusses the relationship between verbal and visual signs system in cigarette advertisements in Youtube. The purpose of this study is to describe how the visual and verbal signs system are the basic elements of message formation and the meaning relations of connotations that appear in cigarette advertisements in Youtube. This becomes interesting due to the prohibition against showing examples of cigarette products themselves in the mass media. Cigarette advertisements show their own uniqueness, namely that they always show the male figure in their advertisements with various kinds of activities they do. The method used in this research is descriptive qualitative method with data analysis techniques using Charles Sanders Peirce's semiotic analysis. The data in this study were obtained from downloaded video advertisements in Youtube in the form of six cigarette advertising videos, then playing the video into pieces of images, all of which would be analyzed. The writer the analyze the relationship between the verbal sign system and visual signs, in the form of images and writings on cigarette advertisements on Youtube with the meanings contained therein and provide interpretations of the connotative meaning of the interaction of verb signs and visual signs. Based on the analysis, there are verbal and visual signs that have their own meanings, which try to communicate their message through these signs. Verbal signs in cigarette advertisements on Youtube can be found in the tagline, which contains the meaning that appears in the visual sign of the ad. In this case, verbal signs are an important element in adapting the advertising language used to foster reminders and brand awareness of these cigarette products. Visually, cigarette advertisements on Youtube show the independence of these men, indicating the independent nature of men who are able to solve all their problems alone. The construction of the visualization of the male figure in this advertisement also displays a positive image, namely the loving nature of pets. The ability of men to be able to manipulate is also a new image in the male image.
\end{abstract}

Keywords: advertising, relationship, verbal, visual, Youtube

Abstrak
Penelitian ini membicarakan relasi sistem tanda verbal dan visual dalam iklan rokok
di Youtube. Oleh karena itu, tujuan penelitian ini adalah mendeskripsikan bagaimana
sistem tanda visual dan verbal yang menjadi elemen dasar pembentukan pesan dan
relasi makna konotasi muncul pada iklan rokok di Youtube. Karena memiliki
keterbatasan dalam memvisualisasikan keunggulan dan produk rokok tersebut,
diperlukan adanya kreativitas dan inovasi di dalamnya yang menekankan pada imaji
dan impresi terhadap produk rokok tersebut. Di samping itu, iklan rokok juga


memperlihatkan keunikan tersendiri, yaitu selalu memperlihatkan sosok lelaki dengan berbagai macam aktivitas yang dilakukannya. Metode yang digunakan dalam penelitian ini adalah metode deskriptif kualitatif dengan teknik analisis data menggunakan analisis semiotika Charles Sanders Peirce. Data dalam penelitian ini diperoleh dari mengunduh video iklan yang ada pada Youtube berupa enam video iklan rokok kemudian memutar video tersebut menjadi potongan gambar yang semuanya akan dianalisis dan menganalisis hubungan antara sistem tanda verbal dan tanda visual berupa gambar dan tulisan yang ada pada iklan rokok di Youtube dengan makna yang terkandung di dalamnya dan memberikan interpretasi terhadap makna konotasi atas interaksi tanda verba dan tanda visual. Hasil penelitian menunjukkan bahwa dalam iklan rokok di Youtube terdapat tanda verbal dan tanda visual yang memiliki makna-makna tersendiri yang dicoba dikomunikasikan melalui tandatanda tersebut. Tanda verbal dalam iklan rokok di Youtube dapat ditemukan pada tagline-nya yang di dalamnya terdapat merepresentasikan makna yang dimunculkan dalam tanda visual iklan tersebut. Dalam hal ini, tanda verbal merupakan elemen yang penting dalam mengadaptasikan bahasa iklan yang digunakan untuk menumbuhkan reminder dan brand awareness terhadap produk rokok tersebut. Secara visual, kemandirian yang dimiliki oleh laki-laki tersebut mengindikasikan sifat independen laki-laki yang mampu menyelesaikan semua permasalahannya sendiri. Konstruksi visualisasi sosok laki-laki dalam iklan juga menampilkan citra positif, yaitu sifat penyayang terhadap hewan peliharaan. Kemampuan laki-laki untuk dapat memanipulasi juga merupakan gambaran yang baru pada pencitraan laki-laki.

Kata Kunci: iklan, relasi, verbal, visual, Youtube

\section{PENDAHULUAN}

Di antara berbagai iklan, iklan rokok merupakan iklan yang paling kontroversial. Iklan rokok sudah menjadi perdebatan yang lama, khususnya di Indonesia. Data WHO menunjukkan 144 negara telah melarang iklan rokok di media penyiaran. Di Asia Tenggara, Indonesia merupakan satu-satunya negara yang masih mengizinkan para produsen rokok berkiprah dalam periklanan. Oleh karena itu, tidak mengherankan apabila Indonesia merupakan salah satu pangsa pasar penjualan rokok terbesar di dunia. Hal ini menimbulkan persepsi di masyarakat bahwa selama ini kebijakan iklan rokok di media penyiaran masih berpihak pada kepentingan industri rokok dan media, bukan pada kesehatan masyarakat. Media penyiaran memilih untuk mendapatkan iklan dari industri rokok yang mencapai triliunan rupiah setiap tahunnya.

Riset menunjukkan iklan rokok merupakan kontributor penting bagi kebiasaan merokok di kalangan anak muda. Masifnya iklan rokok di televisi menjadi salah satu pemicu dalam memengaruhi perilaku merokok remaja. Standar maskulinitas di Indonesia yang bersifat kontekstual juga menjadi salah satu penyebab tingginya perilaku merokok remaja. Hal ini membuktikan bahwa iklan rokok memiliki keefektifan promosi produk. Penyajian bahasa yang persuasif menjadi bagian yang penting memengaruhi calon konsumen (Sukamto, 2012). Lebih lanjut, dua fungsi utama dalam periklanan, yaitu literal dan simbolik, diusulkan oleh Patrick (Patrick, 2018). Kedua fungsi utama ini berperan penting dalam periklanan secara visual. Literal dalam visual menyediakan informasi-informasi faktual, baik 
mengenai produk maupun layanan, sedangkan simbolisasi dalam iklan merepresentasikan gambaran-gambaran produk yang memuat makna yang dimaksud (Patrick, 2018). Gambaran ini tentu saja akan mengarahkan siapa konsumen yang dituju sehingga dalam iklan tersebut diyakini memuat ideologiideologi tertentu yang dikolaborasikan dalam tanda visul dan verbal.

Penelitian mengenai iklan rokok baik yang ada di media cetak maupun media televisi sebenarnya telah banyak dilakukan, misalnya Representasi Maskulinitas pada Iklan Cetak oleh Yoyoh Hareyah (Hareyah, 2015). Dalam penelitian ini yang dibahas adalah aspekaspek desain grafis dan komunikasi visual yang ada pada iklan cetak dengan menggunakan metode semiotika Roland Barthes, yaitu melihat apakah ada mitos di sana yang muncul di balik iklan tersebut.

Ernawati (Ernawati, 2019) membahas Analisis Tanda pada Karya Desain Komunikasi. Penelitian tersebut membahas makna yang dikomunikasikan tanda dapat dijelajah dengan penafsiran berdasarkan konsep keilmuan yang dihubungkan dengan mitos atau budaya dengan menggunakan pendekatan semiotika Roland Barthes sebagai teori analisisnya. Penelitian yang dilakukan oleh Faturahman berjudul Semiotik Komunikasi Visual berkenaan dengan system pemaknaan dalam iklan rokok U Mild (Faturahman, 2017).

Penelitian-penelitian tersebut memiliki kesamaan dalam hal objek penelitiannya, yaitu mengenai iklan rokok dan bagaimana desain yang harus dilakukan agar iklan tersebut efektif menyampaikan pesan kepada audiensinya. Di samping itu, kajian yang dilakukan pada penelitian tersebut lebih banyak digunakan pada kajian ilmu komunikasi, sedangkan penelitian ini lebih mengarah pada relasi sistem tanda yang ada di dalam iklan rokok tersebut yang meliputi pengunaan aspek bahasa dan visual yang menyertai iklan tersebut dan ditayangkan pada kanal Youtube.

Oleh karena itu, tujuan dari penelitian ini adalah sistem tanda verbal dan tanda visual serta relasi makna yang terkandung pada iklan rokok yang ada di Youtube. Penelitian ini diharapkan dapat dijadikan referensi dan acuan yang memadai bagi para peneliti berikutnya, terutama mahasiswa program studi Pendidikan Bahasa dan Sastra Indonesia.

Metode yang digunakan dalam penelitian ini adalah metode deskriptif kualitatif. Untuk mencapai deskriptif yang kualitatif, penelitian ini menerapkan beberapa tahapan, yaitu (1) penyediaan data, (2) tahap analisis data, dan (3) tahap penyajian data (Ratna, 2010:97-98).

Data primer yang dianalisis diambil dari video yang ditayangkan di Youtube. Untuk keperluan penelitian, tidak semua versi iklan rokok dijadikan sebagai subjek, tetapi hanya enam versi saja. Sumber data dari penelitian adalah video iklan rokok. Teknik pengumpulan data dilakukan dengan mengambil video dari situs yang bisa dipertanggungjawabkan keabsahannya. Langkah yang diambil dalam menganalisis data adalah menemukan sistem verbal dan visual yang terdapat pada tiap potongan video iklan rokok tersebut dan selanjutnya memberikan interpretasi terhadap tandatanda tersebut dan menganalisis hubungan antartanda untuk menemukan makna yang terdapat dalam iklan tersebut.

\section{Sistem Tanda Verbal}

Sistem tanda adalah konsep kunci dalam semiotika dan digunakan untuk merujuk kepada sistem tanda dan hubungan antar tanda. Oleh karena itu, dalam pengertian sistem tanda verbal, yang muncul adalah sistem yang digunakan sebagai proses penyampaian pikiran, pesan, atau perasaan seseorang kepada orang lain 
dengan menggunakan simbol yang menggunakan satu kata atau lebih sebagai medianya. Media yang sering dipakai ialah bahasa. Bahasa sudah dianggap menjadi suatu sistem kode verbal.

Dalam pandangan lain, menurut Saussure, tanda adalah kesatuan dari dua bidang yang tidak dipisahkan (Pradopo, 1991). Di mana ada tanda di sana ada sistem. Artinya, sebuah tanda mempunyai dua aspek yang ditangkap oleh kedua indra manusia, yaitu signifier (bidang penanda atau bentuk) penanda yang terletak pada tingkatan ungkapan (level of expression) yang memiliki wujud seperti bunyi, huruf, kata, gambar, dan sebagainya; dan signified (bidang penanda atau konsep atau makna) penanda yang terletak pada tingkat isi atau gagasan (level of content).

Menurut Peirce, tanda (representament) ialah sesuatu yang dapat mewakili sesuatu yang lain dalam batasbatas tertentu (Pierce, 1982). Tanda akan selalu mengacu kepada sesuatu yang lain (denotatum), mengacu berarti mewakili atau menggantikan. Tanda dapat berfungsi jika diinterpretasikan dalam benak penerima tanda melalui interpretant (pemahaman makna yang muncul dalam diri penerima tanda). Pemahaman tersebut diperoleh dari pengetahuan tentang sistem tanda dalam suatu masyarakat. Untuk tanda dan denotatanya, Peirce memfokuskan diri pada tiga aspek tanda, yaitu ikon, indeks, dan simbol.

\section{Sistem Tanda Visual}

Sistem tanda visual adalah suatu kesatuan yang terdiri atas komponen atau elemen dari tanda visual yang digunakan sebagai proses penyampaian pesan kepada orang lain dengan tidak menggunakan kata-kata. Tanda visual dapat berupa gestur, gerak, isyarat, bahasa tubuh, ekspresi wajah, dan kontak mata. Selain itu, tanda dapat berupa objek, seperti pakaian, potongan rambut, simbol-simbol, dan sebagainya.

Membicarakan sistem tanda visual pada hakikatnya mengarah kepada bidang semiotika komunikasi visual. Semiotika komunikasi visual adalah sebuah upaya memberika interpretasi terhadap keilmuan semiotika itu sendiri, yaitu sebagai metode pembacaan karya komunikasi visual. Dilihat dari sudut pandang semiotika, desain komunikasi visual adalah sistem semiotika khusus dengan perbendaharaan tanda (vocabulary) dan sintak (syntagm) yang khas. Di dalam sistem komunikasi visual melekat fungsi komunikasi, yaitu fungsi tanda dalam menyampaikan pesan dari pengirim pesan kepada para penerima tanda berdasarkan aturan atau kode-kode tertentu.

Semiotika komunikasi menekankan aspek produksi tanda di dalam berbagai rantai komunikasi, saluran, dan media daripada sistem tanda. Di dalam rantai komunikasi tanda ditempatkan dalam rantai komunikasi sehingga mempunyai peran penting dalam penyampaian pesan.

Meskipun objek utama dari komunikasi visual adalah elemenelemen komunikasi yang bersifat visual, yaitu garis, bidang, ruang, warna, bentuk, dan tekstur, pada perkembangannya desain komunikasi visual juga melibatkan elemen-elemen nonvisual, seperti tulisan, bunyi, atau bahasa verbal. Kombinasi elemenelemen visual dengan nonvisual macam ini tampak pada desain iklan.

\section{Makna Denotatif dan Konotatif}

Semua makna diciptakan dengan menggunakan simbol-simbol. Simbol mengacu kepada objek atau peristiwa apa pun yang menunjuk pada sesuatu. Semua simbol melibatkan tiga unsur, yaitu 
simbol itu sendiri, satu rujukan atau lebih, dan hubungan antarsimbol dengan rujukan. Semuanya itu merupakan dasar bagi keseluruhan makna simbolik. Salah satu cara yang digunakan para pakar untuk membahas lingkup makna yang lebih besar adalah dengan membedakan makna denotatif dengan makna konotatif.

Piliang (Piliang, 1998:14) mengartikan makna denotatif adalah hubungan eksplisit antara tanda dan referensi atau realitas dalam pertandaan tahap denotatif. Menurut Piliang (Piliang, 1998:17), makna konotatif meliputi aspek makna yang berkaitan dengan perasaan dan emosi serta nilainilai kebudayaan dan ideologi.

\section{Iklan}

Iklan, sebagai sebuah objek semiotika yang mempunyai objek komunikasi langsung, mengomunikasikan pesan perusahaan atau lembaga tertentu. Oleh sebab itu, di dalam iklan aspek-aspek komunikasi seperti pesan merupakan unsur utamanya.

Sebuah iklan selalu memberikan unsur-unsur tanda berupa objek yang diiklankan. Konteks berupa lingkungan, orang atau makhluk lainnya yang memberikan makna pada objek, dan teks (berupa tulisan) yang memperkuat makna merupakan sebuah wacana semiotik yang membangun sebuah iklan.

Iklan adalah sebuah ajang permainan tanda yang selalu bermain dengan tiga elemen tanda tersebut yang satu dan lainnya saling mendukung. Dalam penelitian mengenai iklan, analisis mengenai konteks yang ditawarkan iklan pada sebuah produk yang diiklankan merupakan aspek yang sangat penting. Lewat konteks tersebut dapat dilihat berbagai persoalan gender, ideologi, fetisisme, kekerasan, simbol, lingkungan, konsumerisme, serta berbagai persoalan lainnya di balik sebuah iklan.

\section{METODE PENELITIAN}

Penelitian ini menggunakan pendekatan deskriptif kualitatif. Metode yang digunakan dalam penelitian ini adalah metode analisis semiotik dengan pendekatan analisis semiotika dari Charles Sanders Peirce. Objek penelitian dalam penelitian ini adalah iklan rokok yang ada di Youtube. Untuk keperluan penelitian, tidak semua versi iklan rokok yang ada di Youtube dijadikan sebagai subjek, tetapi hanya enam versi saja. Yang akan dibahas berupa unit-unit analisis berupa penggunaan bahasa (tanda verbal), visual, dan ekspresi nonverbal dalam tayangan iklan tersebut sehingga akan diperoleh relasi di antara tanda tersebut.

\section{PEMBAHASAN}

Paparan data penelitian mengenai tanda visual dan tanda verbal pada iklan rokok di Youtube terdiri atas enam data iklan rokok. Sistematika penyajian dan deskripsi data didasarkan pada urutan iklan yang ditayangkan di Youtube.

\section{Iklan Versi "Peluk Boleh Lama Jangan"}

Iklan rokok U Mild menampilkan visual tentang para laki-laki muda yang berada di antara komunitasnya. Pada iklan tersebut divisualkan bagaimana mereka bertemu dan menikmati hobi bersamasama dalam suasana yang hangat dan akrab.

Pada awal adegan pembuka diperlihatkan adanya sebuah kafe yang memiliki identitas arsitektur yang khas. Terlihat jelas bahwa bangunan tersebut terletak di tempat strategis dan elite. Kesan diperkuat dengan adanya aktivitas komunitas motor gede yang sedang berkumpul di tempat itu. 
Selanjutnya diperlihatkan adanya dua orang anggota komunitas tersebut bertemu dan saling menyapa dengan penuh kehangatan. Visual yang diperlihatkan dalam adegan ini adalah saat kedua anggota komunitas tersebut berpelukan erat. Selanjutnya, salah seorang tersebut memperlihatkan gestur tangannya dengan membentuk tanda "tos".

Adegan memperlihatkan laki-laki yang macho. Laki-laki macho ditunjukkan oleh penampilan fisik, pakaian, dan aktivitas laki-laki tersebut. Penampilan fisik, seperti otot yang kekar, jenggot, dan gaya rambut yang dimiliki laki-laki dalam iklan ini, menunjukkan bahwa laki-laki memang digambarkan sebagai laki-laki yang macho. Pakaian yang dikenakan oleh karakter laki-laki dalam iklan ini juga menunjang tampilan mereka sebagai laki-laki yang macho.

Dua orang laki-laki dalam iklan U Mild "peluk boleh lama jangan" digambarkan mampu melakukan cara yang tepat dalam mengeskpresikan kehangatan ikatan persahabatannya tanpa membuat orang di sekitarnya mempersepsikan yang berbeda. Hal ini lalu diperkuat dengan adanya visual verbal, yaitu "peluk boleh lama jangan". Iklan ini juga mengarah kepada gaya hidup sosok laki-laki yang hidup mapan dengan gaya hidup yang khas eksekutif muda di kota-kota besar berkenaan dengan hobi motor gede-nya.

\section{Iklan Versi "Cowok Tahu Kapan Harus Bohong"}

Iklan U Mild versi ini dibuka dengan satu adegan seorang perempuan berambut panjang dan memakai kaus pendek terlihat sedang memasak spageti di dapur. Setelah spageti yang telah selesai dimasak perempuan tersebut dihidangkan di meja makan, laki-laki yang berada di depannya mencicipinya. Laki-laki berkaca mata dengan rambut yang diikat ini kemudian menggeser kursi untuk duduk. Mereka berdua duduk di meja makan saling berhadapan. Dengan tangan kanan menyangga dagu, perempuaan ini memandangi dan melihat ekspresi lakilaki yang sedang mencicipi masakannya. Sepertinya si perempuan mengharapkan tanggapan dari si laki-laki atas hasil masakannya. Lalu laki-laki tersebut menunjukkan ekpresi raut wajah senyum memaksa dengan menggunakan gerakan tangan lambang enak. Namun, di balik itu ekspresinya bertolak belakang dengan makna yang diisyaratkan oleh tangannya. Perempuan berambut panjang tersebut begitu senang melihat hasil masakannya mendapat pujian. Ketika ia berdiri dan memalingkan wajahnya, si laki-laki menutupi mulutnya yang hendak memuntahkan makanan.

Laki-laki dalam iklan U Mild versi "cowok tahu kapan harus bohong" terdapat laki-laki yang berdasarkan gayanya tergolong macho. Gaya rambut hingga pakaian yang dikenakan mencerminkan gaya Amerika.

Iklan ini ditampilkan dengan lakilaki yang macho. Laki-laki macho ditunjukkan melalui penampilan fisik, pakaian, dan aktivitas laki-laki tersebut.

Laki-laki dalam iklan U Mild digambarkan pandai dan cerdik melakukan manipulasi yang bertujuan menutupi keadaan yang sebenarnya dengan memberikan kesan yang mendalam terhadap teman wanitanya. Tindak manipulatif yang dilakukannya semata-mata hanyalah untuk mendapatkan apa yang diinginkannya tanpa membuat perempuan menyadari bahwa ada tujuan tersembunyi. Hal ini dilakukan agar perasaan perempuan yang ada di depannya tidak terluka.

Karakter laki-laki yang manipulatif ini sendiri tidak biasa digunakan untuk menggambarkan 
Manipulasi biasanya digunakan oleh perempuan untuk mendapatkan kontrol. Umumnya sikap kontrol ini cenderung didominasi oleh kaum perempuan. Hal ini berlawanan dengan sifat maskulinitas yang dominan. Adanya manipulasi yang dilakukan oleh laki-laki terhadap perempuan justru menunjukkan bahwa perempuan yang mendominasi laki-laki. Adanya ketakutan untuk membuat perempuan marah atau tersakiti malah menjadi tanda bahwa laki-laki tersebut sedang didominasi.

Selanjutnya iklan rokok U Mild versi "cowok tahu kapan harus bohong" juga terdapat seorang perempuan yang berpostur tubuh tinggi, berambut panjang, memakai kaus oblong, dan bercelana pendek. Dalam perspektif umum biasanya cewek cantik itu bercirikan postur tinggi, rambut panjang, dan hidung mancung. Sosok seperti inilah yang sering kali dijadikan acuan dalam dunia mode, termasuk di dalamnya model iklan. Referensi yang dijadikan pedoman untuk merepresentasikan suatu produk ialah seseorang yang mewakili suatu kelompok tertentu atau orang-orang terkenal lain seperti presenter televisi atau penyiar radio.

Iklan rokok U Mild versi "cowo tahu kapan harus bohong" menggambarkan citra laki-laki itu mampu berkamuflase bergantung pada situasi yang dihadapi. Seperti contoh pada iklan ini, yaitu menghargai hasil dari kerja keras perempuan berupa masakan. Iklan ini juga berasumsi wanita adalah produk lain yang terkesan kurang enak bagi beberapa individu, kadang sebagai objek sasaran produsen. Individu disarankan untuk mampu memilih yang lebih baik.

Isi pesan yang disampaikan oleh iklan rokok U Mild versi "cowo tahu kapan harus bohong" ialah pesan kiasan pertarungan dalam bentuk pesan visual. Kaum laki-laki harus menghargai wanita karena sifat alamiah wanita adalah suka dipuji walaupun itu adalah kebohongan.

\section{Iklan Versi "Cowok Pinter Bagi Waktu"}

Iklan U Mild versi "cowok pintar bagi waktu" dimulai dengan adegan seorang laki-laki dan perempuan sedang berada di sebuah restoran sebagai pasangan kekasih dalam suasana yang romantis. Pada bagian yang lain ternyata di restoran itu ada tampilan layar televisi yang menayangkan pertandingan langsung sepak bola. Keromantisan sikap laki-laki itu mulai terlihat pada saat gestur laki-laki memegang sendok di tangan kanannya dan akan menyuapi makanan kepada perempuan yang ada di depannya.

Ekspresi kegembiraan perempuan terpancar dari mata terpejam dan mulut yang terbuka. Tubuh si perempuan mengarah ke sebelah kiri mengikuti arah suapan dari laki-laki tersebut. Ketika tubuh perempuan bergerak ke sebelah kiri, tampak televisi layar datar yang menempel di dinding di belakang perempuan tersebut menayangkan skor 12 untuk kemenangan klub yang berlambang warna biru.

Saat perempuan hendak menerima suapan dari laki-laki tersebut, ternyata laki-laki ini mengarahkan suapan makanannya ke arah samping. Perempuan tersebut otomatis mengikuti arah suapan. Hal ini sengaja dilakukannya karena laki-laki tersebut ingin terus menyaksikan pertandingan bola tersebut.

Sistem pemaknaan yang muncul dalam iklan U Mild versi ini adalah karakter laki-laki yang dapat dengan mudah menemukan celah dalam hal membagi waktu antara hobi dan menyenangkan hati pasangannya. Dengan memilih waktu dan tempat yang tepat, laki-laki dalam iklan ini dapat mencapai apa yang menjadi tujuannya. 
Bahasa verbal (lisan) yang digunakan pada iklan rokok U Mild mengacu kepada cara pandang bahwa laki-laki mampu menempatkan diri sesuai dengan situasi yang dihadapi. Iklan tersebut mengacu kepada indikasi ingin menyenangkan si wanita dengan keromantisan yang dilakukan dengan mengajaknya makan di restoran. Tentu saja tempat makan malam tersebut memang sudah dipilih oleh laki-laki tersebut, yaitu tersedianya media televisi yang secara rutin menyiarkan siaran langsung pertandingan sepak bola. Gambaran gestur manipulatif sengaja ditampilkan dengan penempatan posisi duduk laki-laki tersebut yang berhadapan dengan layar televisi. Kemampuan lakilaki seperti inilah yang diharapkan dalam iklan U Mild, yaitu dapat secara tepat menempatkan diri sehingga terhindar dari situasi yang sulit antara menyenangkan hati pasangan dan hobinya.

\section{Iklan Rokok Versi "Tiap Luka Punya Cerita"}

Iklan rokok U Mild versi "tiap luka punya cerita" menceritakan tiga laki-laki yang sedang berada di sebuah ruang ganti. Laki-laki tersebut saling menunjukkan bekas luka mereka dan menceritakan bagaimana kejadian yang mereka alami pada saat mendapatkan luka tersebut.

Visualisasi iklan rokok U Mild versi ini diawali dengan memperlihatkan tiga laki-laki yang berada di sebuah ruang ganti. Objek di dalam gambar ini ialah tiga laki-laki yang sedang melakukan kegiatan masing-masing. Pada gambar dua ini terlihat seorang laki-laki yang mengenakan pakaian berwarna hitam sedang memperlihatkan bekas luka yang terdapat di lengan kirinya. Untuk memperlihatkan karakter masingmasing, tampilan bekas luka yang terdapat pada lengan kiri objek yang mengenakan kaos hitam diperjelas. Pada gambar ini menandakan adanya hubungan personal di antara ketiga lakilaki tersebut. Pada gambar tiga diperlihatkan adegan seorang pengendara motor yang terjatuh dari sepeda motornya dan di belakangnya terdapat dua orang laki-laki yang sedang melihat kejadian tersebut. Pengendara motor tersebut adalah laki-laki yang sedang memperlihatkan bekas luka yang terdapat di lengannya.

Pada adegan 3 diperlihatkan dua orang laki-laki yang saling berhadapan. Laki-laki yang mengenakan pakaian hitam dan putih menunjuk ke arah bekas luka yang terdapat di pelipis kanan lakilaki yang mengenakan handuk berwarna biru di lehernya. Pada adegan 4, terdapat dua orang laki-laki yang sedang melakukan perkelahian. Laki-laki yang gundul dan mengenakan kemeja berwarna biru melepaskan sebuah pukulan kepada laki-laki berbaju merah tua sehingga terpental keras ke arah kaca. Laki-laki yang terpental tersebut adalah laki-laki yang memiliki luka di pelipis kanan yang terdapat pada gambar 4 .

Pada gambar 5 diperlihatkan lakilaki yang mengenakan handuk di leher dan laki-laki yang mengenakan kaus hitam putih sedang memperhatikan lakilaki yang sedang duduk dan mengarahkan jari telunjuk ke arah dadanya seolah-olah memberi tahu bahwa di dadanya terdapat sebuah bekas luka. Adegan dalam gambar ini menandakan bahwa ketiga laki-laki yang terlihat di gambar memiliki kedekatan atau mengenal satu sama lain. Laki-laki yang sedang duduk ke arah lakilaki yang mengenakan baju berwarna hitam seraya mengarahkan tangan kanan ke arah dadanya menandakan bahwa lakilaki tersebut menggunakan isyarat atau bahasa nonverbal untuk menyampaikan bahwa luka yang ia miliki terdapat di dalam dada atau hatinya.

Pada gambar 6 terdapat seorang laki-laki yang memperlihatkan sebuah 
foto seorang wanita. Laki-laki tersebut ingin memberitahukan bahwa bekas luka yang terdapat di dadanya yang diperlihatkan pada gambar 6 disebabkan oleh seorang wanita. Pada gambar 7, lakilaki yang sedang duduk memperlihatkan foto seorang wanita yang diperlihatkan pada gambar 6 kepada dua orang laki-laki yang berdiri. Pada gambar ini terdapat tulisan kode cowok \#182 "tiap luka punya cerita" yang berarti setiap luka yang dialami pasti mempunyai cerita.

\section{Iklan Versi "Cowok Lebih Tahu Loyal Gak Kenal Waktu"}

Pada iklan ke lima ini terlihat tiga orang laki-laki baru saja keluar dari sebuah kafe. Hal tersebut terlihat dari bentuk bangunan yang menyerupai kafe dan tulisan yang berada di tengah bangunan tersebut memeperjelas nama bangunan itu. Tiga laki-laki tampak keluar dari kafe tersebut. Dilihat dari gestur dan keakraban, mereka adalah sahabat. Berjabatan tangan menandakan bahwa mereka akan berpisah satu sama lain. Perpisahan tersebut menjadikan kisah baru dalam hidup tiga laki-laki yang bernama Kris, Abi, dan Ben. Mereka berpisah karena ingin mencari jati dirinya masing-masing. Kris mencoba memulai petualangan baru dengan menikah, Abi mencoba menjadi seorang fotografer, dan Ben membuka sebuah kafe yang diberi nama Bens Barber and Cafe. Meskipun , sempat terpisah karena memulai sebuah petualangan baru dalam hidupnya, mereka tetap dipertemukan dalam pekerjaan yang mereka jalani yang ternyata membawa mereka melanjutkan kebersamaan.

Iklan ini menyatakan bahwa "cowok lebih tahu loyal gak kenal waktu" memberikan makna adanya kebersamaan dan kesetiakawanan yang erat satu sama lain. Walaupun dalam urusan pekerjaan memiliki perbedaan satu sama lain, mereka tetap bertahan.

\section{Iklan Versi "Kalo Cinta Gak Pandang Bulu"}

Iklan ketujuh ini menceritakan seorang laki-laki yang menggunakan jaket kulit berwarna hitam keluar dari sebuah mobil berwarna hitam dan langsung masuk ke dalam rumah. Ketika sudah berada di dalam rumah, lelaki ini kemudian melepaskan jaketnya dan meletakkan jaket tersebut di gantungan baju yang sudah tersedia. Laki-laki ini langsung beranjak ke dapur dan membuka kulkas serta mengambil sebuah botol yang berisikan susu putih. Lalu ia beranjak dari dapur dan segera mencari piring dan menuangkan susu tersebut ke dalamnya. Setelah itu, ia lantas memanggil kedua kucing berambut tebal miliknya agar meminum susu yang telah diberikannya. Iklan ini menandakan bahwa laki-laki tersebut baik hati dan penyanyang.

Secara fisik, tampilan laki-laki dalam iklan ini memperlihatkan sosok laki-laki yang macho dan jantan. Tampilan ini diperkuat dengan adanya kumis dan jenggot. Laki-laki dalam iklan edisi ini mengenakan jaket kulit berwarna hitam dan terdapat kacamata hitam menggantung di kausnya. Kedua aksesoris ini merupakan aksesoris yang sering digunakan untuk menggambarkan maskulinitas dan biasanya terdapat pada karakter pahlawan.

Dalam iklan edisi "kalo cinta ga pandang bulu", laki-laki diperlihatkan masuk ke apartemen yang luas. Harga rata-rata dari apartemen yang luasnya setengah dari apartemen yang ada di gambar tersebut sekitar Rp400 juta. Lakilaki tersebut juga ditampilkan memiliki sebuah mobil, yaitu Ford Mustang Sportsroof 1971. Harga dari mobil ini juga berkisar di angka \$20.000. Gambaran seperti ini memberikan 
simbolisasi kesuksesan yang dicapai seorang laki-laki. Untuk menandai dan mempertegas citra kesuksesan tersebut ditampilkan adanya gestur melebarkan tangannya ke sisi kursi sebelahnya yang berarti sedang merasa percaya diri dan nyaman. Posisi ini dinamakan sebagai pose dominan.

\section{PENUTUP}

Hasil penelitian yang dilakukan menunjukkan bahwa dalam iklan rokok di Youtube terdapat tanda verbal dan visual yang memiliki makna tersendiri yang mencoba dikomunikasikan kepada audiensi. Tanda verbal dalam iklan rokok di Youtube dapat ditemukan pada tagline-nya yang di dalamnya merepresentasikan makna yang dimunculkan dalam tanda visual iklan tersebut. Dalam hal ini, tanda verbal merupakan elemen yang penting dalam mengadaptasikan bahasa iklan yang digunakan untuk menarik perhatian dan memancing rasa penasaran audiensi. Keberadaan tanda verbal ini dimaksudkan untuk menumbuhkan reminder dan brand awareness terhadap produk rokok tersebut.

Secara visual, iklan rokok di Youtube memperlihatkan tampilan lakilaki yang memiliki kehidupan yang mapan dan gaya hidup yang ideal berdasarkan status sosialnya di masyarakat. Oleh karena itu, dalam iklan ini ditampilkan laki-laki yang macho. Laki-laki macho ditunjukkan melalui penampilan fisik, pakaian, dan aktivitas laki-laki tersebut. Penampilan fisik, seperti otot yang kekar, jenggot, bekas luka, dan gaya rambut yang dimiliki lakilaki dalam iklan ini menunjukkan bahwa laki-laki memang digambarkan sebagai laki-laki yang macho. Kemandirian yang dimiliki oleh laki-laki tersebut mengindikasikan sifat independen laki- laki yang mampu menyelesaikan semua permasalahannya sendirian.

Konstruksi visualisasi sosok lakilaki dalam iklan ini juga menampilkan citra positif. Hal ini digambarkan melalui kasih sayang laki-laki kepada lawan jenis atau kepada hewan peliharaan. Kemampuan laki-laki untuk memanipulasi juga merupakan gambaran yang baru pada pencitraan laki-laki. Laki-laki dalam iklan rokok digambarkan mampu melakukan cara yang pandai untuk mencapai tujuan yang dikehendaki tanpa membuat perempuan yang ada di depannya terendahkan. Hal ini dilakukan agar perasaan perempuan yang ada di depannya tidak terluka.

Setelah melakukan penelitian dan melihat hasil yang didapatkan, penulis berpendapat bahwa iklan rokok di Youtube telah mampu menghadirkan konsep-konsep tanda verbal dan visual dalam mengomunikasikan konsep iklannya sebagai bentuk relasi di antara keduanya. Konsep iklan ini juga memakai konsep verbal agar pesan yang ingin disampaikan lebih mudah tersampaikan kepada pemirsa. Bahasa verbal sendiri merupakan bahasa yang umum digunakan di kalangan masyarakat sehingga dengan adanya penggunaan bahasa tersebut dan ditunjang dengan visualisasi, pesan yang ingin disampaikan akan lebih mudah dimengerti secara keseluruhan. Iklan rokok diharapkan dapat lebih banyak dan lebih kuat lagi dalam mempresentasikan ide-idenya, terutama yang dalam konsepnya terdapat makna sosial yang dapat menginspirasi masyarakat.

\section{DAFTAR PUSTAKA}

Ernawati. (2019). nalisis Tanda Pada Karya Desain Komunikasi Visual. Deskovi, 2(1), 27-34.

Faturahman, W. (2017). Semiotika 
Komunikasi Visual: Sistem

Pemaknaan Iklan Rokok U Mild Versi Sepanjang Jalan Kenangan. Lontar, 2(1), 33-40.

Hareyah, Y. (2015). Representasi Maskulinitas Pada Iklan Cetak (Analisa Semiotika Iklan Rokok Djarum Black). Communicare, 4(2), 11-18.

Patrick, V. (2018). The visual element in advertising. In University of Houston (Ed.), Advertising visuals (p. 8). Texas.

Pierce, C. S. (1982). Logic as Semiotics: The Theory of Sign. Bloomington: Indiana University Press.

Piliang, Y. A. (1998). Sebuah Dunia yang Dilipat, Realitas Kebudayaan Menjelang Milenium Ketiga dan Matinya Posmodernisme. Bandung: Mizan.

Pradopo, R. D. (1991). Pengkajian Puisi: Analisis Strata Norma dan Analisis Struktural dan Semiotik. Yogyakarta: Gadjah Mada University Press.

Ratna, N. K. (2010). Metodologi Penelitian Kajian Budaya dan Ilmu Sosial, Humaniora pada Umumnya. Yogyakarta: Pustaka Pelajar.

Sukamto, K. E. K. D. (2012). Bahasa iklan dan pemberdayaan perempuan: Sebuah kajian komunikasi dan bahasa terhadap iklan tv produk Citra. Ranah, 1(3), $1-12$. 